\title{
Chromosomal diversity in Apis mellifera carnica from Serbia ${ }^{1}$
}

\author{
Zoran STANIMIROVIC ${ }^{\mathrm{a}}$, Jevrosima STEVANOVIC ${ }^{\mathrm{a} *}$, Marko ANDJELKOVIC ${ }^{\mathrm{b}}$ \\ a Department of Biology, Faculty of Veterinary Medicine, University of Belgrade, Boulevard JNA 18, \\ 11000 Belgrade, Yugoslavia \\ ${ }^{b}$ Institute of Zoology, Faculty of Biology, University of Belgrade, Studentski trg 16, 11000 Belgrade, Yugoslavia
}

Received 21 May 2002 - Revised 10 February 2004 - Accepted 5 July 2004

Published online 31 January 2005

\begin{abstract}
Comparative chromosomal investigations of three honey bee ecotypes of A. m. carnica (the Banat, the Timok and the Syenichko-Peshterski ecotype) from Serbia were performed. G-band analyses revealed differences between Timok and Banat honey bee ecotypes in chromosomes 2, 4, 11 and 13 . Between the Timok and Syenichko-Peshterski ecotypes, differences were observed for chromosomes 1, 12, 15 and 16. The greatest differences in G-band number and distribution were registered between the Syenichko-Peshterski and Banat ecotypes in chromosomes 1, 2, 4, 11, 12, 13, 15 and 16. The results point to great interecotype variability of G-band pattern of chromosomes of the carniolan honey bee in Serbia. To preserve such honey bee diversity in Serbia, the three investigated ecotypes require attention for conservation.
\end{abstract}

Apis mellifera carnica / polymorphism / G-band / chromosomes / diversity

\section{INTRODUCTION}

Biodiversity implies biological heterogeneity. In other words, the entirety of the existing animal and plant genotypes and phenotypes, i.e. the natural hereditary quality, and thereby the maintenance of the variability of animal and plant genomes are involved (Dempfle, 1990; Hodgers, 1991; Beilharz et al., 1993). According to Torp-Donner and Juga (1997), the biodiversity within all the existing ecosystems is indispensable for their stability, functioning, mutual interaction and survival. On the basis of the UN program, pertaining to the protection of the environment and in cooperation with the European Association for Animal Production, the Food and Agriculture Organization of the United Nations (FAO, 1989) initiated a program to record all the breeds and lines of both domestic and other economically important animals. Similarly, the adoption the Conven- tion on Biological Diversity in Brazil in 1992, showed the need for preservation of biodiversity at the international level (Griffiths, 1998).

As our contribution to the above-mentioned global program, and to support the concept of the maintenance of biological diversity (Dempfle, 1990; Hodgers, 1991; Beilharz, 1993), we undertook an investigation of G-band polymorphism of Apis mellifera carnica Pollmann chromosomes sampled from the territory of Serbia. The cytogenetic method used was in accordance with the FAO's Commission for Animal Genetic Resources (AnGR) list of scientific methods applicable to the characterization and protection of indigenous animal breeds (Draft Curriculum for scientific method coursework, DAD-IS HomePage, 1997; Loftus and Scherf, 1993; Griffiths, 1998).

Badino et al. (1982, 1983) and Sheppard and Berlocher (1985) investigated the genetic variability of Apis mellifera ligustica Spinola

* Corresponding author: biolog@ vet.bg.ac.yu

${ }^{1}$ Manuscript editor: Walter S. Sheppard 
using polymorphic enzyme electrophoresis. The same method was used to study enzyme polymorphism in Apis mellifera L. from Norway (Sheppard and Berlocher, 1984), in honey bees from western Czechoslovakia (Sheppard and McPheron, 1986), in Sicilian honey bees (Badino et al., 1985) and Greek honey bees (Badino et al., 1988). Sheppard (1988) observed a loss of variation in both the number of polymorphic enzymes and the number of allozymes per polymorphic locus in U.S. honey bee populations compared with those of the Old World. Combined analyses of morphological and allozyme variability were undertaken for populations from Kenya (Meixner et al., 1994) and Turkey (Kandemir et al., 2000). DNA analysis of Old World A. mellifera subspecies revealed significantly more variation than had been detected by analysis of enzyme polymorphism and has been used to study natural introgression between subspecies (Smith et al., 1991; Garnery et al., 1992; Meixner et al., 1993), and to test hypotheses concerning subspecies origin, dispersion and biogeography (Garnery et al., 1991; Arias and Sheppard, 1996). Schiff and Sheppard (1995) reported significant differences between feral and commercial populations of honey bees from the southern United States based on mtDNA haplotypes and allozyme variability. Sheppard et al. (1996) examined mtDNA variation among endemic honey bee subspecies using the restriction anzyme Hinfl and identified twenty different mtDNA haplotypes.

The first cytogenetic characterization of the chromosomes of the honey bee Apis mellifera was done by Hoshiba and Kusanagi (1978). They gave a full description of all chromosomes and stated their biometric characteristics. The results of karyotype and banding analyses on haploid males, diploid males and females of A. mellifera were published by Hoshiba (1984a, 1984b). Hoshiba and Okada (1986) presented results of karyological and G-banding analyses of the haploid male of Apis cerana japonica Radoszkowsky and Apis mellifera ligustica, from the cytotaxonomic point of view. To reveal chromosome evolution of bees and wasps, Hoshiba and Imai (1993) studied C-banding patterns of Apis cerana japonica and Apis mellifera ligustica.

The first karyological investigations of honey bees Apis mellifera carnica from Yugo- slav regions (Stanimirovic et al., 1997) showed that, with regard to the biometric value of its chromosomes, the karyotype of the Banat honey bee ecotype corresponded to those of Hoshiba and Kusanagi (1978), therefore the Banat karyotype was taken as referential. The biometric analyses of chromosomes of the two investigated ecotypes, Banat (B) and SyenichkoPeshterski (SP), from Yugoslav territory indicated differences in relative length and centromere index (arm ratio) of their chromosomes. The greatest differences in relative chromosome length were noticed between autosomes Nos. 1, 2, 3, 11, 12, 14 and 15, where the lengths of chromosomes Nos. 1, 2, 3, 6 and 12 were greater in honey bees of Syenichko-Peshterski ecotype, whilst chromosomes Nos. 11, 14 and 15 were longer in honey bees of Banat referential ecotype. The greatest differences in centromere index were noticed between chromosomes Nos. 1, 2, 4 and 16 (Stanimirovic et al., 1998, 1999a, b). Stevanovic (2002) revealed chromosomal and morphometric differences among honey bees belonging to three ecotypes (Banat, Timok and Syenichko-Peshterski ecotypes) from the territory of Serbia; while the results of Pejovic (2001), Stanimirovic et al. (2001, 2002a, b) and Cirkovic (2002) approved the existence of a great intra- and interpopulation variability in exertion of hygienic and grooming behavior of Banat yellow honey bees and Syenichko-Peshterski honey bees. These findings prompted us to perform ultrastructural analyses concerning distribution of euchromatin and heterochromatin of chromosomes of honey bees of the three mentioned ecotypes: Banat (B), Syenichko-Peshterski (SP) and Timok (T), to provide further detailed information on G-band polymorphism of the chromosomes of A. m. carnica from Serbia.

The term "ecotype" implies a genetic variety within a single species, adapted to local ecological conditions (Dumanovic et al., 1985). "Ecotype" is also defined as a race adapted to the selective action of a particular environment. Ecotypes are described as climatic or edaphic. In honey bees, it is a case of climatic ecotypes, because honey bee colonies have biological one-year cycle, adaptable to variable influences of environmental climatic conditions. In every habitat, there is a stable harmony among the cycle of melliferous herbs, climatic changes and the biological cycle of the local honey bee. 


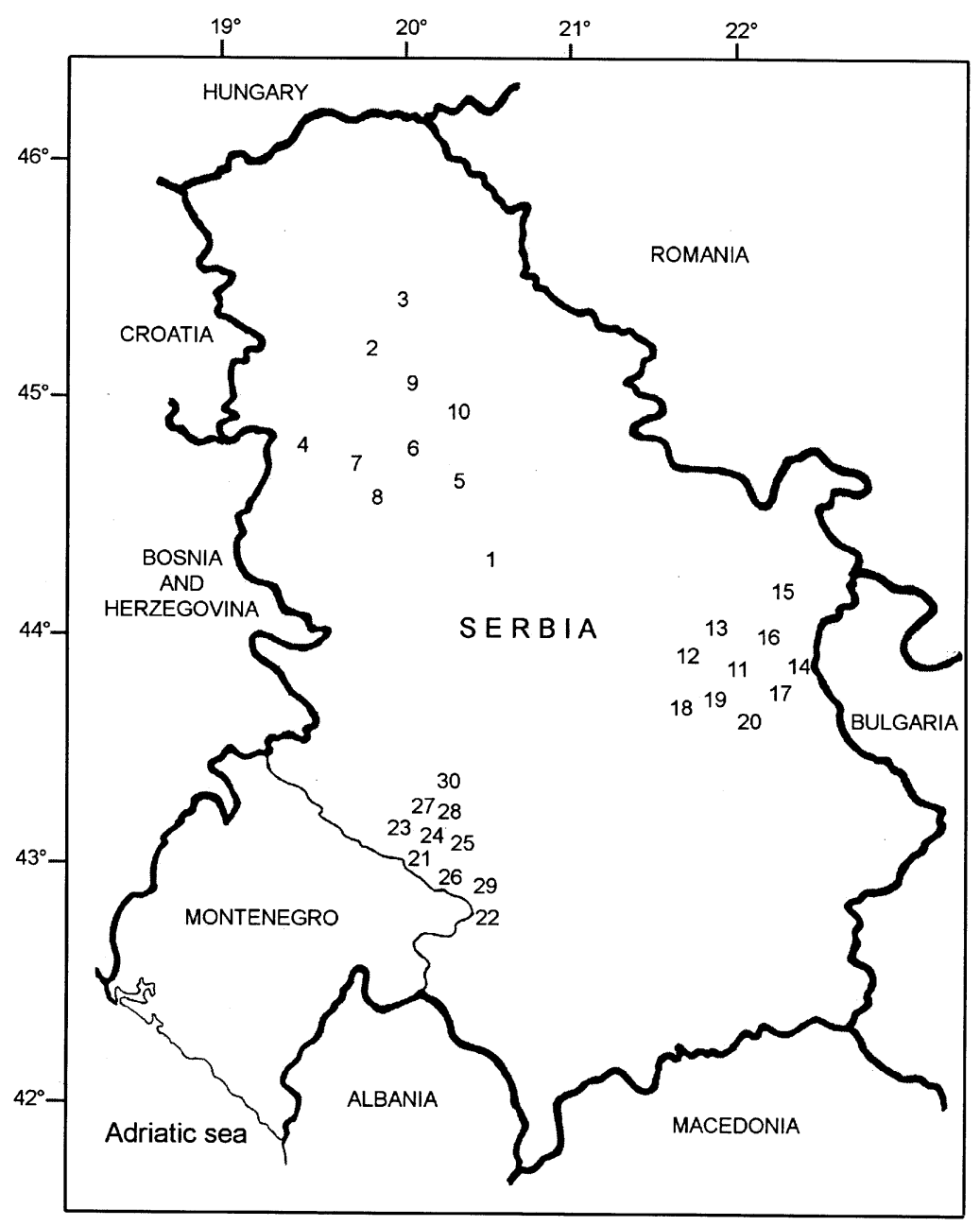

Figure 1. Geographical distribution of the sampled localities: Banat region (localities: 1. Belosavci; 2. Dumbovo; 3. Curug; 4. Dublje; 5. Ripanj; 6. Cerak; 7. Drenovac; 8. Sevarice; 9. Tabanovic; 10. Crna Bara); Timok region (localities: 11. Ilino; 12. Krivi Vir; 13. Lukovo; 14. Stupanj; 15. Metris; 16. Lubnica; 17. Vrazogrnac; 18. Sesalac; 19. Milusinac; 20. Levovik); Syenichko-Peshterski region (localities: 21. Vranovina; 22. Kocarnik; 23. Borostica; 24. Dubovo; 25. Cvijetlje; 26. Livadak; 27. Grabovica; 28. Sare; 29. Pavlje; 30. Gonje).

Thence, the annual cycle of a local honey bee (ecotype) appears as an inheritable developmental form, i.e. as a result of a long adaptation (Bubalo et al., 1994).

It could be considered that honey bees of each ecotype investigated in this study are adapted to specific microclimatic and floristic conditions of the region they inhabit.
Honey bees of Banat ecotype (B) inhabit the Banat region (Fig. 1) an area between the latitudes $44^{\circ} 20^{\prime}$ and $45^{\circ} 30^{\prime}$ and between longitudes $19^{\circ} 20^{\prime}$ and $20^{\circ} 40^{\prime}$; the altitude is from 75 to $165 \mathrm{~m}$. Climate is continental or moderate continental, with an average annual temperature of $12.0^{\circ} \mathrm{C}$, the average minimal temperature of the coldest month being $1.4^{\circ} \mathrm{C}$, and an absolute 
temperature miminum of $11.8^{\circ} \mathrm{C}$. In this region no month with average monthly temperature below $0{ }^{\circ} \mathrm{C}$ has been recorded. The avegare annual precipitation is $58.9 \mathrm{~mm}$.

Honey bees of Timok ecotype (T) are from the Timok region, i.e. between latitudes $43^{\circ} 30^{\prime}$ and $44^{\circ} 10^{\prime}$ and between longitudes $21^{\circ} 40^{\prime}$ and $22^{\circ} 40^{\prime}$. The climate is moderate continental with various modifications depending on altitude, which extends from 120 to $450 \mathrm{~m}$. The average annual temperature is $10.7^{\circ} \mathrm{C}$, the average minimal temperature of the coldest month is $0.6{ }^{\circ} \mathrm{C}$ and the absolute temperature minimum is $-22.2{ }^{\circ} \mathrm{C}$. During January and December, the average monthly temperatures are below $0{ }^{\circ} \mathrm{C}$. The average annual precipitation is $50.0 \mathrm{~mm}$.

The third ecotype, the so called SyenichkoPeshterski ecotype (SP) refers to the Syenichko-Peshterski Plateau. The Plateau spreads in meridian direction between latitudes $43^{\circ} 0^{\prime}$ and $43^{\circ} 30^{\prime}$ and between longitudes $19^{\circ} 45^{\prime}$ and $20^{\circ} 45^{\prime}$, with average altitude $1167 \mathrm{~m}$. The continental climate in this region is characterized with cold winters, abundant precipitation and cool summers. The average annual temperature is $6.4{ }^{\circ} \mathrm{C}$, the average minimal temperature of the coldest month is $-4.33{ }^{\circ} \mathrm{C}$ and the absolute temperature minimum is $-27.6^{\circ} \mathrm{C}$. During summer periods the temperature in this region goes up to $16{ }^{\circ} \mathrm{C}$, which is considerably below the average temperature values for Banat region $\left(23.3{ }^{\circ} \mathrm{C}\right)$ and Timok region $\left(22{ }^{\circ} \mathrm{C}\right)$. During four months, from the begining of December till the end of March, the average monthly temperature in Syenichko-Peshterski region is below $0{ }^{\circ} \mathrm{C}$, which indicates the existence of extremely cold and prolonged winter periods. The average annual precipitation is $69.1 \mathrm{~mm}$.

Bearing in mind all the aforementioned differences among the regions inhabited by the analysed honey bee ecotypes, in addition to the ascertained differences in the external morphology (Stevanovic, 2002), relative length and centromere index of chromosomes (Stanimirovic et al., 1998, 1999a, b; Stevanovic, 2002) and behavioral features (hygienic and grooming) among SP, B and T ecotypes (Pejovic, 2001; Pejovic et al., 2002; Stanimirovic et al., 2001, 2002a, b; Cirkovic, 2002), we undertook to investigate chromosomal diversity of $A$. $m$. carnica by using G-banding method - all this as the first step in our further research into the genetic diversity of honey bees on the territory of Serbia.

\section{MATERIALS AND METHODS}

For chromosomal analyses of honey bees, 12 worker prepupae from each locality were sampled. Prepupae were collected from 10 localities within each investigated region (Banat, Timok and Syenichko-Peshterski), thus 120 prepupae of each ecotype were collected. The names and geographical distribution of the sampled localities are presented in Figure 1. Sampling was carried out from small apiaries that had existed on the same localities at least 50 years, separated from other apiaries by at least $7 \mathrm{~km}$. In these apiaries, honey bee colonies were kept in traditional hives which had never been moved. Requeening of colonies was strictly natural. As those apiaries were rather isolated and foreign queens had never been introduced into them, the genetic influence from other apiaries was minimal.

Only the cerebral ganglia from living worker prepupae, nine to eleven days old, with star-like, reddish eyes, were used for the cytogenetic analysis. Chromosomes from the cerebral ganglia were prepared in accordance with a modified procedure of Hoshiba et al. (1995). G-banding of chromosomes was done by the tripsin-method of Seabright (1971) and Ronne (1991), as modified by Stanimirovic (1999b).

The preparations were examined by an Opton photomicroscope. Photomicrographs of the chromosomes (karyotypes) were taken at the magnification $2000 \times$. In 50 chromosomal sets $(2 \mathrm{n}=32)$ of each ecotype, all chromosomes were analysed. Thus, the analyses of distribution of euchromatin and heterochromatin regions were performed on 1600 chromosomes of each ecotype. Visual comparison of G-band distribution on chromosomes, performed according to Stanimirovic et al. (1999b), provided G-band chromosome patterns of each investigated ecotype.

\section{RESULTS}

The results of ultrastructural analyses of chromosomes (G-band polymorphism) of the studied honey bee ecotypes are shown on the original micrographs (Figs. 2-4). Differences in the number and distribution of G-bands on chromosomes were observed between $\mathrm{T}$ and $\mathrm{B}$ honey bee ecotypes in the case of chromosomes 2, 4, 11 and 13 (Figs. 2, 3, 5). On chromosome 2 of the Thoney bee ecotype, an extra euchromatic band (1a) was observed on the $p-a r m$, 


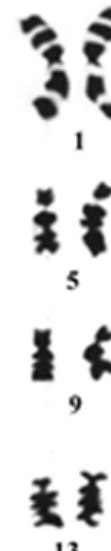

13
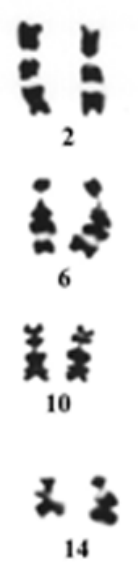
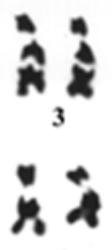

7

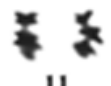

11

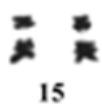

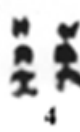

$i^{2}$
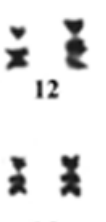

16

Figure 2. G - banded chromosomes of the Banat honeybee ecotype.

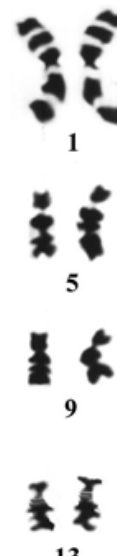

13

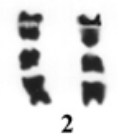

2
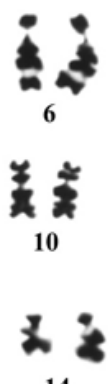

14
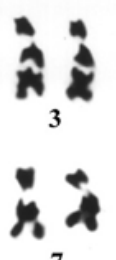

7
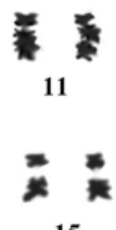

15

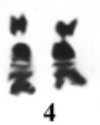

* *

8
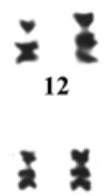

16
Figure 3. G - banded chromosomes of the Timok honeybee ecotype.

compared to the chromosome from the same autosome pair in the B referential ecotype. On chromosomes 4, 11 and 13 of the T ecotype, compared to the same chromosomes in the $B$ referential ecotype, additional bands were detected on q-arms: two additional bands [one heterochromatic $\left(\mathrm{C}_{2}\right)$ and one euchromatic $\left(\mathrm{C}_{3}\right)$ ] in case of chromosome 4 , three additional bands [two heterochromatic $\left(\mathrm{A}_{1 \mathrm{a}}, \mathrm{A}_{1 \mathrm{c}}\right)$ and one euchromatic $\left.\left(\mathrm{A}_{1 \mathrm{~b}}\right)\right]$ in case of chromosome 11 and three additional bands [two euchromatic $\left(\mathrm{A}_{1}, \mathrm{~A}_{3}\right)$ and one heterochromatic $\left.\left(\mathrm{A}_{2}\right)\right]$ in case of chromosome 13 (Fig. 5).
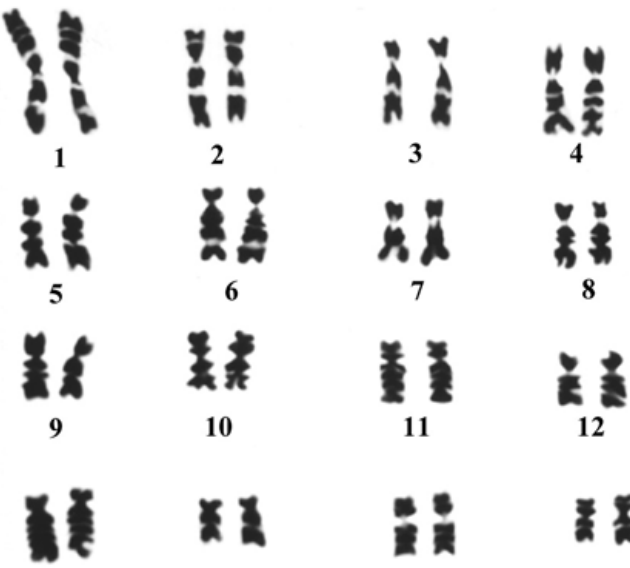

13
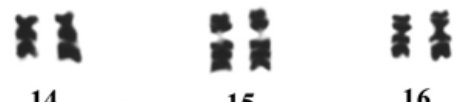

15

16

Figure 4. G - banded chromosomes of the Syenichko-Peshterski honeybee ecotype.

Between SP and T ecotypes, differences in chromatic region distribution were observed for chromosomes 1, 12, 15 and 16 (Figs. 3, 4, $6)$. Two extra bands [one heterochromatic $\left(\mathrm{D}_{2}\right)$ and one euchromatic $\left.\left(D_{3}\right)\right]$ on the $p$-arm were registered on chromosome 1 of the SP ecotype compared to the chromosome from the same autosome pair in the T honey bee ecotype. On chromosomes 12, 15 and 16 of the SP ecotype, additional bands were detected on q-arms: one additional heterochromatic band $\left(\mathrm{A}_{1}\right)$ on chromosome 12 , one additional heterochromatic band $\left(\mathrm{A}_{1}\right)$ on chromosome 15 and one additional heterochromatic band $\left(\mathrm{A}_{1 \mathrm{a}}\right)$ on chromosome 16 (Fig. 6).

The greatest differences in G-band number and distribution were registered between SP and $\mathrm{B}$ referential ecotypes on chromosomes 1 , 2, 4, 11, 12, 13, 15 and 16 (Figs. 2, 4, 7). On chromosome 1 of the SP honey bee, extra heterochromatic $\left(D_{2}\right)$ and euchromatic $\left(D_{3}\right)$ blocks were detected on the p-arm, compared to the chromosome from the same autosome pair in the B honey bee. Moreover, the SP ecotype has one additional, paler euchromatic band $\left(\mathrm{B}_{1 \mathrm{a}}\right)$ on the $\mathrm{p}$-arm of the second pair of autosomes. On chromosome 4 [two additional bands: one heterochromatic $\left(\mathrm{C}_{2}\right)$ and one euchromatic $\left.\left(\mathrm{C}_{3}\right)\right]$, 11 [three additional bands: two heterochromatic $\left(\mathrm{A}_{1 \mathrm{a}}, \mathrm{A}_{1 \mathrm{c}}\right)$ and one euchromatic $\left.\left(\mathrm{A}_{1 \mathrm{~b}}\right)\right], 12$ [one additional heterochromatic band $\left.\left(\mathrm{A}_{1}\right)\right], 13$ [three additional bands: one heterochromatic 


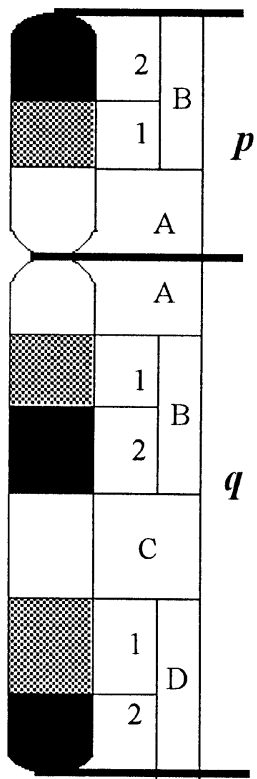

$2 \mathrm{~B}$

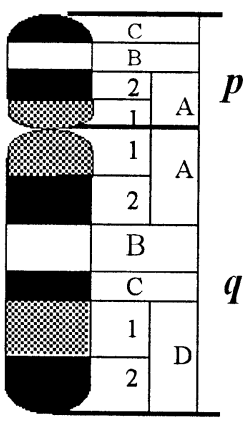

$11 \mathrm{~B}$

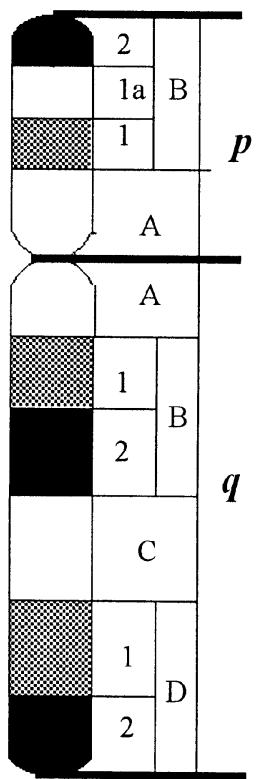

$2 \mathrm{~T}$

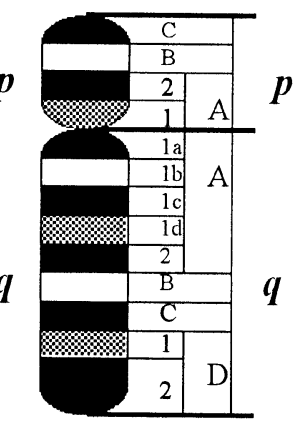

$11 \mathrm{~T}$

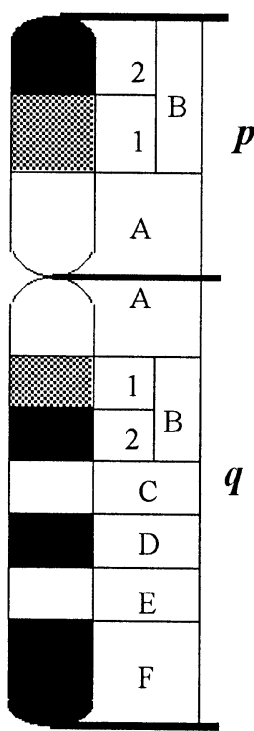

$4 \mathrm{~B}$

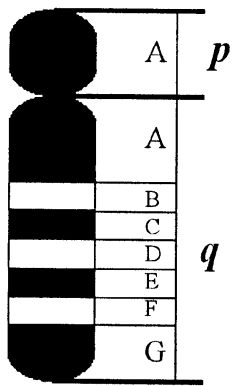

$13 \mathrm{~B}$

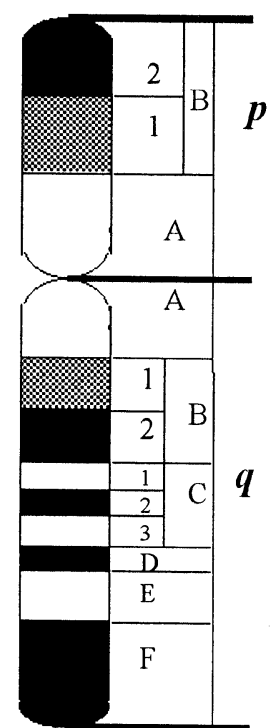

$4 \mathrm{~T}$

Figure 5. Comparative idiogram of chromosomes 2, 4, 11 and 13 with differences in number and distribution of euchromatin and heterochromatin bands of Banat (B) and Timok (T) carniolan honeybee ecotypes.

$\left(\mathrm{A}_{2}\right)$ and two euchromatic $\left.\left(\mathrm{A}_{1}, \mathrm{~A}_{3}\right)\right], 15$ [one additional heterochromatic band $\left.\left(\mathrm{A}_{1}\right)\right]$, and 16 [one additional heterochromatic band $\left(\mathrm{A}_{1 \mathrm{a}}\right)$ ], amplifications of chromosome blocks are detected on the q-arm of the SP honey bee ecotype (Fig. 7).

In honey bees of SP ecotype, out of 120 worker prepupae altogether, $92(76.67 \%)$ had a karyotype with homozygous status for analysed euchromatic and heterochromatic bands. However, in the karyotype of $28 \mathrm{SP}$ worker prepupae $(23.33 \%)$ we noticed the existence of heterozygous status with regard to distribution of euchromatic and heterochromatic bands compared to chromosomes of B referential 


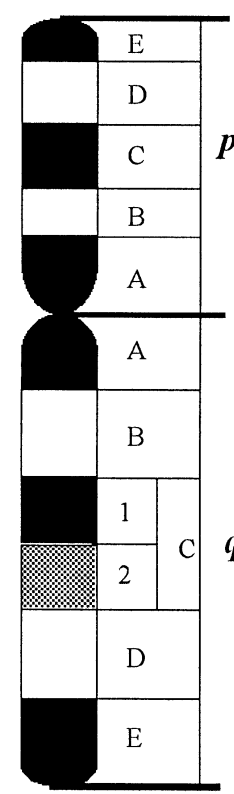

$1 \mathrm{~T}$

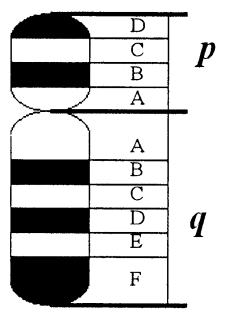

$15 \mathrm{~T}$

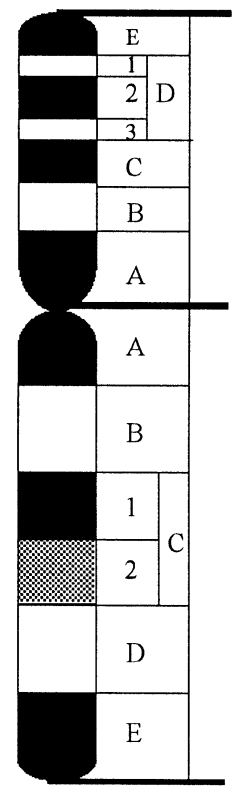

$1 \mathrm{SP}$

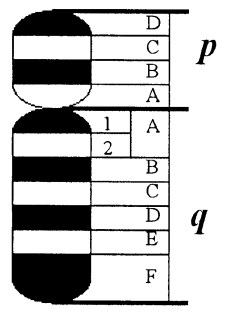

$15 \mathrm{SP}$

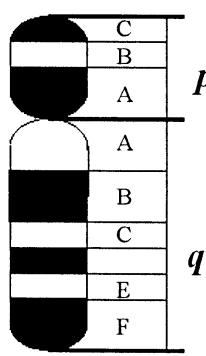

$12 \mathrm{~T}$

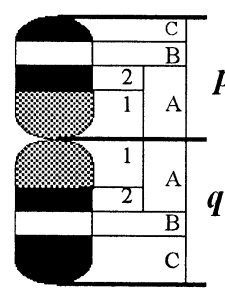

$16 \mathrm{~T}$

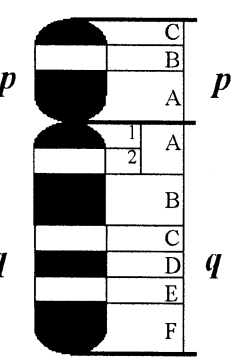

$12 \mathrm{SP}$

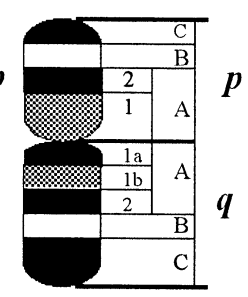

$16 \mathrm{SP}$

Figure 6. Comparative idiogram of chromosomes 1, 12, 15 and 16 with differences in number and distribution of euchromatin and heterochromatin bands of Timok (T) and Syenichko-Peshterski (SP) carniolan honeybee ecotypes.

ecotype. The heterozygous status was observed in: 7 SP prepupae from the locality No. 30, 6 from locality No. 29, 6 from locality No. 27, 5 from locality No. 22 and 4 from locality No. 28.

In honey bees of T ecotype, out of 120 worker prepupae altogether, $106(88.33 \%)$ were homozygous and 14 (11.67\%) heterozygous with regard to distribution of euchromatic and heterochromatic bands in relation to chromosomes of B referential ecotype. The heterozygous status was observed in: $5 \mathrm{~T}$ prepupae from locality No. 15, 4 from locality No. 12, 3 from locality No. 13 and 2 from locality No. 18 .

These data point to the existence of a relatively low level of heterozygosity within the populations of SP and T honey bee ecotypes. Bearing in mind the geographical distribution of the localities, the isolation of the ecotypes, the absence of migratory beekeeping, and the behavior of queens in mating, the observed heterozygosity may represent intrapopulation genetic polymorphism at the G-band level. 

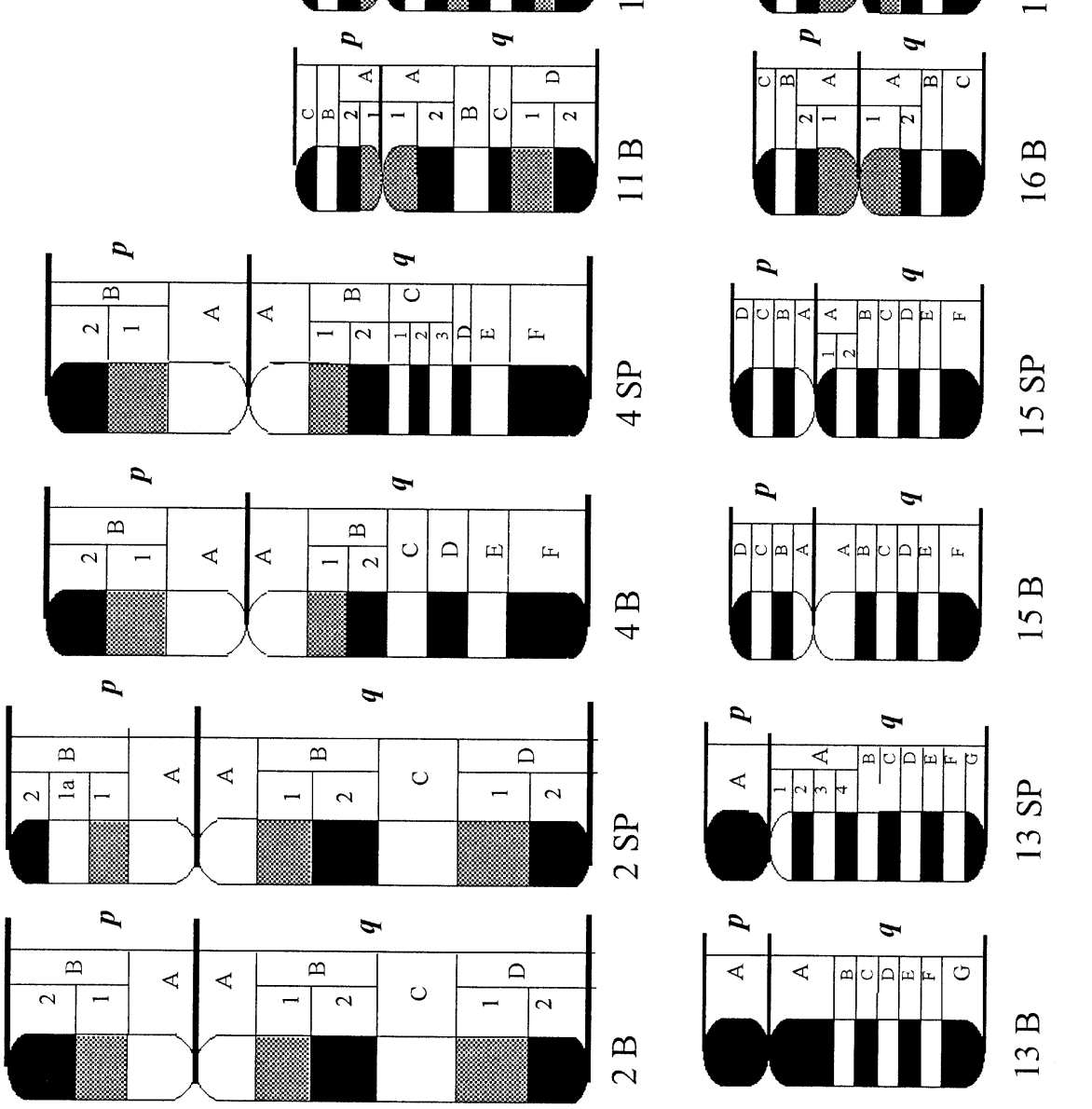

它
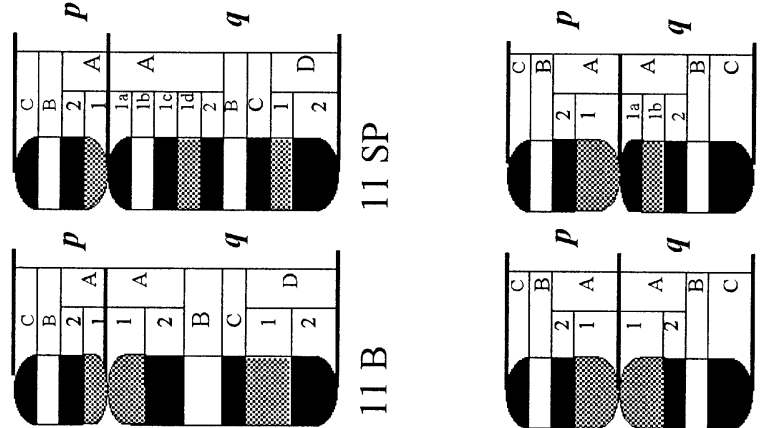

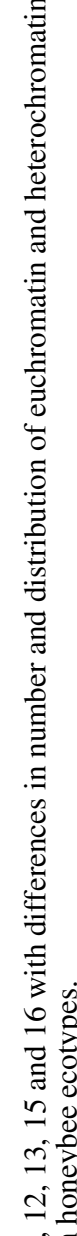
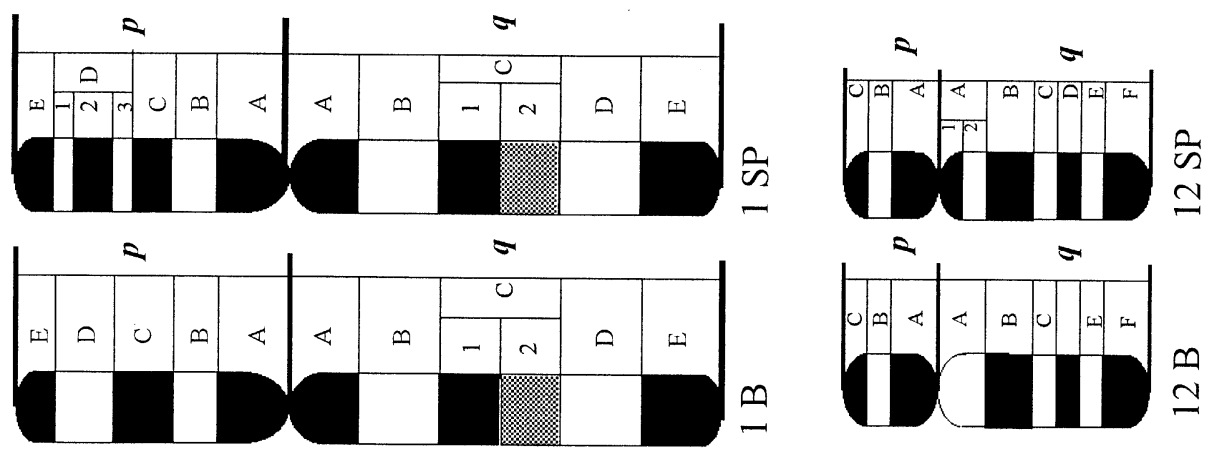

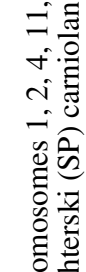




\section{DISCUSSION}

In this study, cytogenetic investigation of three indigenous honey bee ecotypes from Serbia was performed to elucidate polymorphism of G-banding pattern of $A$. $m$. carnica chromosomes. According to Ruttner (1988) several ecotypes of $A$. m. carnica can be recognized on the basis of precise morphometric measurements. Kezic et al. (1994) reported differences in the area of open brood, in the number of drone brood cells and in pollen amount among three ecotypes of $A$. m. carnica: alpine (from Austria), pannonian (from Croatia) and subalpin (from Slovenia). Previous investigations of diversity in A. m. carnica from Serbia revealed differences in the biometric and ultrastructural organizations of chromosomes between B and SP honey bee ecotypes (Stanimirovic et al., 1999a, b), differences in exertion of hygienic and grooming behaviors within and among the same ecotypes (Pejovic, 2001; Pejovic et al., 2002; Stanimirovic et al., 2001, 2002a, b; Cirkovic, 2002), and morphometric differences among honey bees of B, T and SP ecotypes (Stevanovic, 2002).

The comparison of the distribution of euchromatin and heterochromatin on chromosomes in the studied honey bee karyotypes revealed additional and fluctuating tempo in changes established in the amount of euchromatin and heterochromatin of certain chromosomes in SP and T honey bee ecotypes compared to those of the $B$ referential ecotype. The revealed variability suggest that there exists a certain balance in the increase of the overall amount of euchromatin and heterochromatic bands in SP and T ecotypes. These results are in accordance with those of Hoshiba and Imai (1993) who investigated chromosome evolution of bees and wasps on the basis of $\mathrm{C}$-banding pattern analyses, pointing to saltatory and fluctuating growth of heterochromatin after centric fission influencing the number and morphology of chromosomes. These authors suggested that chromosome number of hymenopterans during evolution was increased by centric fission, and arm number by pericentric inversion; but temporary reduction of chromosome number occurred by centric fusion.

Since the mechanism of additional band development and dynamics of band number increase have not investigated, we can only presume that the observed differences on chromosomes of SP and T ecotypes might be the result of fluctuating chromosomal rearrangements (Imai et al., 1988; Hoshiba and Imai, 1993), probably based on spontaneous or induced amplifications of certain chromosomal regions, known to be frequent in chromosomes of mouse-like rodents (Viegas-Pequignot et al., 1983; Agulnik et al., 1988; Stanimirovic et al., 1995).

In this study, the chromosomal differences between $\mathrm{T}$ and SP honey bee ecotypes were registered on 4 chromosomes: Nos. 1, 12, 15 and 16, whereas in SP ecotype a greater number of bands (altogether 5 bands more), were found in relation to the same chromosomes of $\mathrm{T}$ ecotype. Chromosomal differences (in the number of bands) between $\mathrm{T}$ and $\mathrm{B}$ ecotypes were also registered on 4 chromosomes (Nos. 2, 4, 11 and 13), but altogether there were 9 bands more in T ecotype karyotype than in that of B referential ecotype. In the karyotype of the SP ecotype, 14 more bands were found than in that of $\mathrm{B}$ referential ecotype. We conclude that the greatest cytogenetic differences exist between the SP and B honeybee ecotypes, less differences exist between the $\mathrm{T}$ and $\mathrm{B}$ ecotypes and the least occur between the SP and T ecotypes.

The results of this study demonstrate the existence of G-band polymorphism of the chromosomes of the subspecies Apis mellifera carnica in Serbia. The cytogenetic differences among the three investigated honey bee ecotypes, and the data on their hygienic and grooming behaviors (Pejovic, 2001; Pejovic et al., 2002; Stanimirovic et al., 2001, 2002a, b; Cirkovic, 2002), suggest that these ecotypes may represent a novel source of genetic variation for breeding programs, and, therefore, require attention for conservation. Furthermore, our results suggest that even more extensive genetic variability could be dispersed within the three ecotypes. Additional studies of genetic polymorphism at the molecular level should provide higher resolution of ecotypic relationships.

\section{ACKNOWLEDGEMENTS}

The authors wish to thank the Ministry of science, technology and development of Serbia for providing financial support (Project No. 1870). 
Résumé - Diversité chromosomique chez l'abeille Apis mellifera carnica de Serbie. La biodiversité de l'abeille domestique Apis mellifera carnica Pollm de Serbie a été étudiée du point de vue du polymorphisme de la bande $\mathrm{G}$ des chromosomes. Trois écotypes ont été échantillonnés dans 3 régions de Serbie géographiquement définies et caractérisées par des microclimats spécifiques et des conditions floristiques nombreux. Dans la région de Banat, les abeilles vivent dans des conditions de microclimat de plaine et appartiennent à l'écotype Banat (B). Les 2 autres écotypes - Timok (K) et Syenichko-Peshterski (SP) - vivent dans des conditions de microclimat et de flore très spécifiques de la région de Timok et du plateau de Syenichko-Peshterski respectivement.

On a observé des différences dans le nombre et la répartition des bandes $\mathrm{G}$ sur les chromosomes entre les écotypes $\mathrm{T}$ et $\mathrm{B}$ pour 4 chromosomes $(2,4,11$ et 13), la caryotype T ayant 9 bandes de plus que l'écotype de référence B (Fig. 5). On a observé des différences dans la répartition de la région chromique entre les écotypes SP et T pour 4 chromosomes également $(1,12,15$ et 16$)$, mais avec seulement 5 bandes supplémentaires dans le caryotype SP par rapport au caryotype $\mathrm{T}$ (Fig. 6). Les différences les plus grandes concernant le nombre et la répartition des bandes $\mathrm{G}$ ont été enregistrées entre les écotypes SP et $\mathrm{B}$, où 8 chromosomes $(1,2,4,11,12,13,15$ et 16$)$ présentent des différences avec 14 bandes supplémentaires dans le caryotype de l'écotype SP par rapport à l'écotype de référence $\mathrm{B}$ (Fig. 7). Cette étude prouve l'existence d'un polymorphisme de la bande $\mathrm{G}$ des chromosomes au sein de la race Apis mellifera carnica de Serbie. Les 3 écotypes peuvent représenter une source de variation génétique pour des programmes de sélection et méritent donc des mesures pour leur conservation. En outre nos résultats suggèrent l'existence d'une variabilité génétique encore plus étendue parmi les 3 écotypes. D'autres études du polymorphisme génétique au niveau moléculaire devraient fournir une définition plus forte des relations entre écotypes.

Apis mellifera carnica / polymorphisme / bande G / chromosome / diversité

Zusammenfassung - Mannigfaltigkeit der Chromosomen ei der Honigbiene Apis mellifera carnica aus Serbien. Die vorliegende Studie untersucht die Biodiversität der Honigbienen Apis mellifera carnica Pollm. aus Serbien im Hinblick auf den G-Bandenpolymorphismus der Chromosomen. In drei geographisch definierten Regionen Serbiens, die charakterisiert sind hinsichtlich zahlreicher mikroklimatischer und floristischer Bedingungen, wurden drei Ökotypen der Bienen gesammelt. Die in der Banat-Region unter einem Tieflandmikroklima lebenden Bienen wurden dem Banat-Ökotyp (B) zugeordnet. Die anderen beiden Ökotypen, die unter den mikroklimatisch und floristisch hochspezifischen
Bedingungen der Timok-Region und des Syenichko-Peshterski-Plateaus leben, wurden als Timok(T), beziehungsweise als (SP) Ökotypen bezeichnet. Die Honigbienenökotypen $\mathrm{T}$ und $\mathrm{B}$ wiesen an 4 Chromosomen Unterschiede in der Zahl und Verteilung der G-Banden auf, wobei der Karyotype des T-Ökotyps 9 Banden mehr aufwies als der Referenzökotyp B (Abb. 5). Auch für die SP- und T-Ökotypen wurden an 4 Chromosomen Unterschiede in der Chromatinverteilung festgestellt, wobei der Karyotyp des SP-Ökotyps 5 Banden mehr aufwies als der T-Ökotyp (Abb. 6). Die grössten Unterschiede in der Zahl und Verteilung der G-Banden wurden zwischen dem SP- und dem B-Ökotyp registriert, und zwar in 8 Chromosomen $(1,2,4,11,12,13,15$ und 16), die im SP-Ökotyp insgesamt 14 Banden mehr aufwiesen als im Referenzökotyp B (Abb. 7).

Die Ergebnisse dieser Studie zeigen einen G-Bandenpolymorphismus der Chromosomen für die Subspezies Apis mellifera carnica in Serbien. Alle drei Ökotypen können eine Quelle genetischer Variation für Zuchtprogramme darstellen und sind deshalb für Konservierungsmassnahmen von Bedeutung. Des weiteren weisen unsere Ergebnisse auf die Existenz einer weitaus umfassenderen genetischen Variabilität innerhalb der drei Ökotypen hin. Eine höhere Auflösung der Ökotypbeziehungen ist deshalb in molekularen Studien zum genetischen Polymorphismus zu erwarten.

Apis mellifera carnica / Polymorphismus / G-Bande / Chromosom / Mannigfaltigkeit

\section{REFERENCES}

Arias M.C., Sheppard W.S. (1996) Molecular phylogenetics of honey bee subspecies (Apis mellifera L.) inferred from mitochondrial DNA sequence, Mol. Phylogenet. Evol. 5, 557-566.

Agulnik S.I., Gorlov I.P., Agulnik A.I. (1988) New variant of chromosome No. 1 in domestic mouse, Cytology 30, 773-778 (in Russian).

Badino G., Celebrano G., Manino A. (1982) Genetic variability of Apis mellifera ligustica Spin. in a marginal area of its geographical distribution, Experientia 38, 540-541.

Badino G., Celebrano G., Manino A. (1983) Population structure and $M d h-1$ locus variation in Apis mellifera ligustica, J. Hered. 74, 443-446.

Badino G., Celebrano G., Manino A., Longo S. (1985) Enzyme polymorphism in the Sicilian honeybee, Experientia 41, 752-754.

Badino G., Celebrano G., Manino A., Ifantidis D. (1988) Allozyme variability in Greek honeybees (Apis mellifera L), Apidologie 19, 377-386.

Beilharz R., Luxford B., Wilkinson J. (1993) Quantitative genetics and evolution: Is our understanding 
of genetics sufficient to explain evolution? J. Anim. Breed. Genet. 110/3, 161-170.

Bubalo D., Langer Z., Drazic M., Pechhacker H., Poklukar J., Kezic N. (1994) Wintering of different carnica ecotypes (Apis mellifera carnica) in the north west part of Croatia, in: Gomercic H. (Ed.), Proc. 5th Congr. Croatian Biologists, Oct. 3-7th, Pula, Croatia, pp. 228-229 (in Croatian).

Cirkovic D. (2002) Reproductive-productive and hygienic-grooming characterization of SyenichkoPeshterski honey bee ecotype, M.Sc. thesis, Univ. Belgrade, Yugoslavia.

DAD-IS HomePage (1997) Draft Curriculum for scientific method coursework. http://dad.fao.org/en/ Home.htm (accessed on 15 November 2004).

Dempfle L. (1990) Conservation, creation and utilization of genetic variation, J. Anim. Sci. 73, 25932600.

Dumanovic J., Marinkovic D., Denic M. (1985) Dictionary of genetics, Naucna knjiga, Beograd (in Serbian).

FAO - Food and Agriculture Organization of the United Nations (1989) Programs for the Preservation of Animal Genetic Resources, FAO, Rome, Italy.

Garnery L., Vautrin D., Cornuet J.M., Solignac M. (1991) Phylogenetic relationships in the genus Apis inferred from mitochondrial DNA sequence data, Apidologie 22, 87-92.

Garnery L., Cornuet J.M., Solignac M. (1992) Evolutionary history of the honey bee Apis mellifera inferred from mitochondrial DNA analysis, Mol. Ecol. 1, 145-154.

Griffiths H.I. (1998) Conservation and Balkan biodiversity-plenary lecture, in: Petkovski S. (Ed.), Proc. 2nd Int. Congr. Biodiversity, Ecology and Conservation of the Balcan Fauna (BIOECCO 2), Sept. 16-20, Ohrid, Macedonia, pp. 42-46.

Hodgers J. (1991) Sustainable development of animal genetic resources, World review of animal zootechnic, Anim. Genet. Res. 3/91, 2-10.

Hoshiba H. (1984a) Karyotype and banding analyses on haploid males of the honey bee (Apis mellifera), Proc. Jpn Acad. Ser. B 60, 122-124.

Hoshiba H. (1984b) The C-Banding analysis of the diploid male and female honey bee (Apis mellifera), Proc. Jpn Acad. Ser. B 60, 238-240.

Hoshiba H., Kusanagi A. (1978) Karyological study of honeybee, J. Apic. Res. 17, 105-109.

Hoshiba H., Okada I. (1986) G-Banding analyses of male chromosomes in Apis cerana and A. mellifera ligustica, Apidologie 17, 101-106.

Hoshiba H., Imai H.T. (1993) Chromosome evolution of bees and wasps (Hymenoptera, Apocrita) on the basis of C-banding pattern analyses, Jpn J. Entomol. 61, 465-492.
Hoshiba H., Duchateau M.R., Velthuis H.W. (1995) Diploid males in the bumble bee Bombus terrestris (Hymenoptera) karyotype analyses of diploid females, diploid males and haploid males, Jpn J. Entomol. 63, 203-207.

Imai H.T., Taylor R.W., Crosland M.W.J., Crozier R.H. (1988) Modes of spontaneous chromosomal mutation and karyotype evolution in ants with reference to the minimum interaction hypothesis, Jpn J. Genet. 63, 159-185.

Kandemir I., Kence M., Kence A. (2000) Genetic and morphometric variation in honeybee (Apis mellifera L.) populations of Turkey, Apidologie 31, 343-356.

Kezic N., Pechhacker H., Poklukar J., Bubalo D., Drazic M., Ruttner F. (1994) Comparison of brood and pollen amount and productivity of 3 strains of A. m. carnica, Apidologie 25, 485-487.

Loftus R., Scherf B. (1993) World watch list of domestic animal diversity, First edition, FAO/UNEP, Rome.

Meixner M.D., Sheppard W.S., Poklukar J. (1993) Asymmetrical distribution of a mitochondrial DNA polymorphism between 2 introgressing honey bee subspecies, Apidologie 24, 147-153.

Meixner M.D., Sheppard W.S., Dietz A., Krell R. (1994) Morphological and allozyme variability in honey bees from Kenya, Apidologie 25, 188-202.

Pejovic D. (2001) Investigations of hygienic and grooming behaviour of honey bee subspecies Apis mellifera carnica in disease resistance, M.Sc. thesis, Univ. Belgrade, Yugoslavia.

Pejovic D., Vucicevic M., Stanimirovic Z. (2002) Grooming behaviour in varoosis resistance in two honeybee ecogeographic varieties (Apis mellifera carnica) from Serbia, Apiacta 37, 65-70.

Ronne M. (1991) High resolution banding present aspects, Genet. Sel. Evol. 23 (Suppl. 1), 49s-55s.

Ruttner F. (1988) Biogeography and taxonomy of honey bees, Springer-Verlag, Berlin.

Seabright M. (1971) A rapid banding technique for human chromosomes, Lancet 2, 971-972.

Schiff N., Sheppard W. (1995) Genetic analysis of commercial honey bees (Hymenoptera: Apidae) from the southeastern United States, J. Econ. Entomol. 88, 1216-1220.

Sheppard W.S. (1988) Comparative study of enzyme polymorphism in United States and European honey bee (Hymenoptera: Apidae) populations, Ann. Entomol. Soc. Am. 81, 886-889.

Sheppard W.S., Berlocher S.H. (1984) Enzyme polymorphism in Apis mellifera from Norway, J. Apicult. Res. 23, 64-69.

Sheppard W.S., Berlocher S.H. (1985) New allozyme variability in Italian honey bees, J. Hered. 76, 4548. 
Sheppard W.S., McPheron B.A. (1986) Genetic variation in honey bees from an area of racial hybridization in western Czechoslovakia, Apidologie 17, 21-32.

Sheppard W.S., Rinderer T.E., Meixner M.D., Yoo H.R., Stelzer N.M., Schiff N.M. Kamel S.M., Krell R. (1996) Hinfl variation in mitochondrial DNA of Old World honey bee subspecies, J. Hered. 87, 35-40.

Smith D.R., Palopoli M.F, Taylor B.R., Garnery L., Cornuet J.M., Solignac M., Brown B. (1991) Geographical overlap of two mitochondrial genomes in Spanish honeybees (Apis mellifera iberica), J. Hered. 82, 96-100.

Stanimirovic Z., Vucinic M., Soldatovic B., Vucicevic M. (1995) A large acrocentric chromosome in the first pair of autosomes in natural populations of Mus musculus, Linne 1758, Acta Vet. (Beograd) $45,155-160$.

Stanimirovic Z., Popeskovic D., Markovic B. (1997) Investigations of chromosomal polymorphism of some indigenous honey bee ecotypes (Apis mellifera) of Yugoslav region, Savremena Poljoprivreda (Novi Sad) 47, 253-260.

Stanimirovic Z., Popeskovic D., Pejovic D. (1998) Specificites of ultrachromosomal structure of the Peshtersko-Sjenichky ecotype of the honeybee (Apis mellifera, Linne), in: Petkovski S. (Ed.), Proc. 2nd Int. Congr. Biodiversity, Ecology and Conservation of the Balcan Fauna (BIOECCO 2), Sept. 16-20, Ohrid, Macedonia, p. 87.

Stanimirovic Z., Popeskovic D., Pejovic D. (1999a) Biodiversity of the honeybee Apis mellifera, Linne (1758), from the Yugoslav regions: I - The biometric variability of the chromosomes of the Banat and Syenichko-Peshterski ecotypes, Acta Vet. (Beograd) 49, 199-206.

Stanimirovic Z., Vucinic M., Stevanovic J. (1999b) Biodiversity of the honeybee Apis mellifera, Linne (1758), from some Yugoslav regions: II Ultrastructural chromosomal differences between Banat and Syenichko-Peshterski honeybee ecotype, Acta Vet. (Beograd) 49, 207-214.

Stanimirovic Z., Stevanovic Jevrosima, Pejovic D., Mirilovic M. (2001) Hygienic and grooming behaviour in disease resistance of two honeybee ecogeographic varieties (Apis mellifera carnica) from Serbia, Mellifera 1-2, 56-61.

Stanimirovic Z., Pejovic D., Stevanovic J., Vucinic M., Mirilovic M. (2002a) Investigations of hygienic behaviour and disease resistance in organic beekeeping of two honeybee ecogeographic varieties from Serbia, Acta Vet. (Beograd) 52, 169-180.

Stanimirovic Z., Pejovic D., Stevanovic Jevrosima (2002b) Hygienic behavior in disease resisteance of two honeybee ecogeographic varieties (Apis mellifera carnica) from Serbia, Apiacta 37, 24-31

Stevanovic J. (2002) Investigations of morphometric and chromosomal variability in diversity preserving of Carniolan honey bee (Apis mellifera carnica Pollmann, 1879) in Serbia, M.Sc. thesis, Univ. Belgrade, Yugoslavia.

Torp-Donner H., Juga J. (1997) Sustainability-a challenge to animal production and breeding, Agr. Food Sci. Finland 6, 229-239.

Viegas-Pequignot E., Dutrillaux B., Prod Homme M., Petter F. (1983) Chromosomal phylogeny of Muridae: a study of 10 genera, Cytogenet. Cell Genet. 35, 269-278. 